\section{Journal Bic Journal BiNET}

Journal of Bioscience and Agriculture Research

Home page: www.journalbinet.com/jbar-journal.html

\title{
Screening of brinjal lines to high salinity levels
}

\section{A. F. M. Jamal Uddin ${ }^{a}$, S. Mutahera ${ }^{a}$, H. Mehraj ${ }^{b}$, K. Momena ${ }^{c}$ and A. S. M. Nahiyan ${ }^{c}$}

apept. of Horticulture, Sher-e-Bangla Agricultural University, Dhaka, Bangladesh bThe United Graduate School of Agricultural Sciences, Ehime University, Japan cAdvanced Seed Research and Biotech Center, ACI Limited, Dhaka, Bangladesh

$\bowtie$ jamal4@yahoo.com (Jamal Uddin, A. F. M.), Published: 25 March 2016

\begin{abstract}
A pot experiment was conducted at the Sher-e-Bangla Agricultural University, Bangladesh during the months of November 2012 to April 2013 for screening the salt tolerant brinjal lines. Ten lines coded from $V_{1}$ (Line-1) to $V_{10}$ (Line-10) were executed under different salinity conditions ( $S_{0}$ : Control; $S_{1}: 12 \mathrm{dS} / \mathrm{m}$ and $S_{2}: 16 \mathrm{dS} / \mathrm{m}$ ) following completely randomized design (CRD) with three replication. Maximum yield was provided by $V_{1}$ and $V_{6}(2.4 \mathrm{~kg} / \mathrm{plant})$ in $12 \mathrm{dS} / \mathrm{m}$ salinity level and $V_{6}$ provided the maximum yield (1.3 $\mathrm{kg} /$ plant) which was closely followed by $V_{1}(1.2 \mathrm{~kg} /$ plant $)$ in 16 $\mathrm{dS} / \mathrm{m}$ salinity level whereas $4.1 \mathrm{~kg} /$ plant and $3.8 \mathrm{~kg} /$ plant from $V_{6}$ and $V_{1}$ respectively in control. From the current study it can be stated that $V_{6}$ and $V_{1}$ lines were the best lines to grow in the highly saline affected areas in Bangladesh but varietal development form promising line and further field trials in different areas is recommended.
\end{abstract}

Key Words: Solanum melongena, Brinjal lines, Salinity levels, Growth and Yield

\begin{abstract}
Please cite this article as: Jamal Uddin, A. F. M., Mutahera, S., Mehraj, H., Momena, K. \& Nahiyan, A. S. M. (2016). Screening of brinjal lines to high salinity levels. Journal of Bioscience and Agriculture Research, 07(02), 630-637.
\end{abstract}

This article is distributed under terms of a Creative Common Attribution 4.0 International License.

\section{Introduction}

Salinity affected area is increasing day by day and spreading all over the country (Mondal et al., 2011). Salinity is affecting potential yield of some crops in salinity affected coastal areas of Bangladesh. Due to evident lower yield, in some areas lands remain as fallow during some parts of a year. Salinity problems can be severe in arid and semi-arid regions since precipitation is not sufficient and water supplies are also scarce as compared to water needs for crop production (Lamsal et al., 1999). Salinity can reduce evapo-transpiration by making soil water less available for plant and reduces potential energy of soil water solution (Allen et al., 1998). Brinjal (Solanum melongena L.) belongs to Solanaceae family is considered one of the most popular vegetable in Bangladesh. Its demand is increasing day by day throughout the year while production is far from the requirements and or varies year to year. Brinjal was classified as a moderately (Maas, 1984) to highly (Bresler et al., 1982) sensitive crop but it has great potentiality to grow in saline soil. Keeping the above point in view the current study was conducted to search salt tolerant brinjal lines at different salinity level and to bring the uncultivable land of the highly saline affected area under cultivation. 


\section{Materials and Methods}

A pot experiment was conducted at Horticultural Farm of the Sher-e-Bangla Agricultural University, Bangladesh during the months of November 2012 to April 2013 following completely randomized design with three replication for screening the salt tolerant brinjal lines. The pot size was 14 inch which was filled with $8 \mathrm{~kg}$ soil. Seeds were sown on the seedbed in $10^{\text {th }}$ October and seedlings were transplanted into the pot on $12^{\text {th }}$ November. Ten lines coded from $V_{1}$ (Line-1) to $V_{10}$ (Line-10) were executed under different salinity conditions $\left(\mathrm{S}_{0}\right.$ : Control; $\mathrm{S}_{1}: 12 \mathrm{dS} / \mathrm{m}$ and $\left.\mathrm{S}_{2}: 16 \mathrm{dS} / \mathrm{m}\right)$. Lines were collected from abroad. Control plants were not exposed to salinity whereas for the $12 \mathrm{dS} / \mathrm{m}$ and 16 $\mathrm{dS} / \mathrm{m}$ salinity level $6.6 \mathrm{~g}$ ACI salt/L of water and $8.8 \mathrm{~g}$ ACI salt/L of water were given to each pot respectively. Saline solutions were placed in the plastic bowl placed under the pots. Manures and fertilizers were used as recommended by Bangladesh Agricultural Research Institute (Mondal et al., 2011). The entire amount of organic manure, TSP, Gypsum, Borax and half of the MP were applied during final pot soil preparation. The remaining half of MP and entire urea applied in three equal installments, $1^{\text {st }}$ at 15 days after planting, $2^{\text {nd }}$ at flowering and the $3^{\text {rd }}$ at fruit maturity stages. Data were collected on plant height, leaf area, chlorophyll content, days to fruiting (visual observation), number of flower bud/plant, number of flower/plant, number of fruit/plant, fruit length, fruit diameter, fruit weight and yield/plant. Digital caliper (DC-515) and electronic precision balance were used for measuring fruit diameter and fruit weight, yield/plant respectively. Collected data were statistically analyzed using MSTAT-C program, mean was calculated and analysis of variance for each of treatment was represented by F-test. Differences between treatments were evaluated by Least Significance Difference (LSD) test at 5\% level of significance (Gomez and Gomez, 1984).

\section{Results}

Plant height: Plant height of brinjal lines varied significantly at different days after transplanting also at different salinity levels. It was found that $\mathrm{V}_{2}$ provided the tallest $(70.5 \mathrm{~cm}, 50.5 \mathrm{~cm}$ and $50.5 \mathrm{~cm}$ at control $12 \mathrm{dS} / \mathrm{m}$ and $16 \mathrm{dS} / \mathrm{m}$ respectively) plant at 95 days after transplanting (Figure 01).

Leaf area: Leaf area was measured at 40 days after transplanting and showed significant differences among the lines at different salinity levels. In control, maximum leaf area was provided by $\mathrm{V}_{7}(113.8$ $\left.\mathrm{cm}^{2}\right)$ followed by $V_{6}\left(106.5 \mathrm{~cm}^{2}\right)$ while minimum from $V_{2}\left(37.5 \mathrm{~cm}^{2}\right)$ (Table 01). On the other hand, $V_{5}$ provided maximum leaf area $\left(58.6 \mathrm{~cm}^{2}\right.$ and $43.6 \mathrm{~cm}^{2}$ for the $12 \mathrm{dS} / \mathrm{m}$ and $16 \mathrm{dS} / \mathrm{m}$ respectively) under saline conditions (Table 01).

Chlorophyll content: Chlorophyll content was also measured at 40 days after transplanting and showed significant differences among the lines at different salinity levels. However, maximum chlorophyll content was observed in $\mathrm{V}_{6}(59.2 \%, 53.5 \%$ and $44.3 \%$ in control, $12 \mathrm{dS} / \mathrm{m}$ and $16 \mathrm{dS} / \mathrm{m}$ respectively) while minimum in $\mathrm{V}_{8}\left(46.4 \%\right.$ and $43.5 \%$ for control and $12 \mathrm{dS} / \mathrm{m}$ salinity level) and $\mathrm{V}_{10}$ (37.5\% for $16 \mathrm{dS} / \mathrm{m}$ salinity level) (Table 01 ).

Days to fruiting: Line $-1\left(\mathrm{~V}_{1}\right)$ was provided early fruiting $(49.4,54.4$ and 62.4 days at control, $12 \mathrm{dS} / \mathrm{m}$ and $16 \mathrm{dS} / \mathrm{m}$ respectively) whereas late fruiting was found from V3 (94.4, 98.4 and 100.4 days at control, $12 \mathrm{dS} / \mathrm{m}$ and $16 \mathrm{dS} / \mathrm{m}$ respectively) (Table 02). From the findings of the present study, it can be stated that brinjal plant provided early fruiting when they were in saline stress.

Number of flower bud/plant, flower/plant and fruit/plant: Maximum number of flower bud was provided by $\mathrm{V}_{9}(80.4 /$ plant $)$ at control, $\mathrm{V}_{7}(70.4 /$ plant $)$ at $12 \mathrm{dS} / \mathrm{m}$ and $\mathrm{V}_{9}(53.4 /$ plant $)$ at $16 \mathrm{dS} / \mathrm{m}$ while minimum was in $\mathrm{V}_{1}(61.4 /$ plant $)$ at control, $\mathrm{V}_{1} \& \mathrm{~V}_{3}(58.4 / \mathrm{plant})$ at $12 \mathrm{dS} / \mathrm{m}$ and $\mathrm{V}_{1}(45.4 /$ plant $)$ at $16 \mathrm{dS} / \mathrm{m}$ (Table 02). Maximum number of flower was provided by $\mathrm{V}_{9}\left(74.4 /\right.$ palnt) at control, $\mathrm{V}_{7}$ (65.4/plant) at $12 \mathrm{dS} / \mathrm{m}$ and $\mathrm{V}_{9}$ (48.4/plant) at $16 \mathrm{dS} / \mathrm{m}$ while minimum was in $\mathrm{V}_{1}$ (56.4/plant) at control, $\mathrm{V}_{2}\left(52.4 /\right.$ plant) at $12 \mathrm{dS} / \mathrm{m}$ and $\mathrm{V}_{1}(39.4 /$ plant) at $16 \mathrm{dS} / \mathrm{m}$ (Table 03). Maximum number of fruit was provided by $\mathrm{V}_{1}$ (47.4/plant) (followed by $\mathrm{V}_{6} \& \mathrm{~V}_{8}$ ) at control, $\mathrm{V}_{1}$ (34.4/plant) (followed by $\mathrm{V}_{4}$ $\left.\& \mathrm{~V}_{2}\right)$ at $12 \mathrm{dS} / \mathrm{m}$ and $\mathrm{V}_{4}\left(23.4 /\right.$ plant) (followed by $\mathrm{V}_{2} \& \mathrm{~V}_{6}$ ) at $16 \mathrm{dS} / \mathrm{m}$ while minimum was in $\mathrm{V}_{4}$ (39.4/plant at control) and $\mathrm{V}_{10}$ (26.4/plant and 17.4/plant at $12 \mathrm{dS} / \mathrm{m}$ and $16 \mathrm{dS} / \mathrm{m}$ respectively) (Table 03). 
From the result of the current study as stated in Table 02 and 03 , it was observed that $\mathrm{V}_{9}$ provided the maximum number of flower bud and flower but maximum number of fruit was provided by $\mathrm{V}_{1}$ at control condition. On the other hand, $V_{7}$ provided the maximum number of flower bud and flower followed by $V_{9}$ but maximum number of fruit was provided by $V_{1}$ at $12 \mathrm{dS} / \mathrm{m}$ salinity level while $V_{9}$ provided the maximum number of flower bud and flower but maximum number of fruit was provided by $V_{4}$ at $16 \mathrm{dS} / \mathrm{m}$ salinity level. Though $\mathrm{V}_{9}$ and $\mathrm{V}_{7}$ provided maximum flower bud and flower but they were not able to set maximum number of fruit not only in salinity stress but also in control condition.

Fruit length and diameter: Longest fruit was obtained from $V_{1}(12.9 \mathrm{~cm}, 11.4 \mathrm{~cm}$ and $9.2 \mathrm{~cm}$ in control, $12 \mathrm{dS} / \mathrm{m}$ and $16 \mathrm{dS} / \mathrm{m}$ respectively) whereas shortest from $\mathrm{V}_{8}(5.2 \mathrm{~cm}, 4.3 \mathrm{~cm}$ and $3.4 \mathrm{~cm}$ in control, $12 \mathrm{dS} / \mathrm{m}$ and $16 \mathrm{dS} / \mathrm{m}$ respectively) (Table 04 ). On the other hand, $\mathrm{V}_{6}$ provided maximum fruit diameter $(57.7 \mathrm{~mm}, 54.1 \mathrm{~mm}$ and $42.5 \mathrm{~mm}$ in control, $12 \mathrm{dS} / \mathrm{m}$ and $16 \mathrm{dS} / \mathrm{m}$ respectively) while minimum from $\mathrm{V}_{10}(29.5 \mathrm{~mm}, 26.7 \mathrm{~mm}$ and $20.7 \mathrm{~mm}$ in control, $12 \mathrm{dS} / \mathrm{m}$ and $16 \mathrm{dS} / \mathrm{m}$ respectively) (Table 04).

Fruit weight and yield/plant: Fruit weight and yield/plant showed significant variation among the variety at different salinity levels. Maximum fruit weight was found from $\mathrm{V}_{6}(88.7 \mathrm{~g}, 74.8$ and $51.7 \mathrm{~g}$ in control, $12 \mathrm{dS} / \mathrm{m}$ and $16 \mathrm{dS} / \mathrm{m}$ respectively) followed by $\mathrm{V}_{1}(76.8 \mathrm{~g}, 64.6 \mathrm{~g}$ and $50.6 \mathrm{~g}$ in control, 12 $\mathrm{dS} / \mathrm{m}$ and $16 \mathrm{dS} / \mathrm{m}$ respectively) while minimum from $\mathrm{V}_{4}(43.5 \mathrm{~g}, 31.5 \mathrm{~g}$ and $18.3 \mathrm{~g}$ in control, $12 \mathrm{dS} / \mathrm{m}$ and $16 \mathrm{dS} / \mathrm{m}$ respectively) (Table 05 ). On the other hand, maximum yield/plant was recorded from $\mathrm{V}_{6}$ (4.1 kg) followed by $V_{1}(3.87 \mathrm{~kg})$ in control, from $V_{6} \& V_{1}(2.4 \mathrm{~kg})$ in $12 \mathrm{dS} / \mathrm{m}$ also from $V_{6}(1.3 \mathrm{~kg})$ followed by $\mathrm{V}_{1}(1.2 \mathrm{~kg})$ in $16 \mathrm{dS} / \mathrm{m}$ (Table 05$)$.

\section{Best varieties at $12 \mathrm{dS} / \mathrm{m}$ and $16 \mathrm{dS} / \mathrm{m}$ salinity level}

At $12 \mathrm{dS} / \mathrm{m}$ salinity level, maximum no of fruit was found from $V_{1}$ (34.4) followed by $V_{4}$ and $V_{6}(30.4)$ lines (Table 06). Maximum single fruit weight was found from $V_{6}(74.8 \mathrm{~g})$ line which was followed by $\mathrm{V}_{1}\left(64.6 \mathrm{~g}\right.$ ) line (Table 06). On the other hand, maximum yield/plant was fond from $\mathrm{V}_{6}$ and $\mathrm{V}_{1}(2.4 \mathrm{~kg})$ lines which was followed $V_{2}(1.5 \mathrm{~kg}$ ) line (Table 06). At $16 \mathrm{dS} / \mathrm{m}$ salinity level, maximum no of fruit was found from $V_{4}$ (23.4) line followed by $V_{2}$ and $V_{6}$ (22.4) lines (Table 06). Maximum single fruit weight was found from $V_{6}(51.7 \mathrm{~g})$ line which was followed by $\mathrm{V}_{1}(50.6 \mathrm{~g})$ line (Table 06). On the other hand, maximum yield/plant was found from $V_{6}(1.3 \mathrm{~kg})$ line which was followed by $\mathrm{V}_{1}(1.2 \mathrm{~kg})$ line (Table 06).

\section{Discussion}

From the Figure 01, it was observed that brinjal plants under the saline conditions reduced the plant height. It is well known that one of the first plant responses to salinity stress is a reduction in plant growth rate with associated reductions in leaf area available for photosynthesis. Subsequently, excessive accumulation of salts can lead to death of tissues, organs and whole plants (Munns and Termaat, 1986). From the current study, it was observed that leaf area of brinjal plant was dramatically reduced with the increases of saline stress. At higher EC levels $(6.1$ and $8.1 \mathrm{dS} / \mathrm{m})$ the leaf area was restricted (Savvas and Lenz, 1994b). Plant height and leaf elongation decrease with increasing $\mathrm{NaCl}$ in the nutrient solution in tomato (Al-Karaki, 2000; Montesano and van Iersel, 2007). Growth and leaf area development of cotton, bean and tomato were strongly inhibited by salinity (Brugnoli and Lauteri, 1991; Romero-Aranda et al., 2001). Excessive amounts of salt in plants can become toxic in older leaves, causing premature senescence and a reduction in total photosynthetic leaf area (Munns, 2002). Such reductions in leaf area are likely to decrease whole plant photosynthesis and thus growth. Chlorophyll content also reduced when brinjal plants were in salt stress. Plants growing under saline conditions accumulate more $\mathrm{Na}$ resulting ionic imbalance. Increasing $\mathrm{Na}^{+}$uptake had been reported to interfere with uptake of $\mathrm{K}^{+}$(Al-Karaki, 2000; Montesano and van Iersel, 2007; Serrano and Rodriquez-Navarro, 2001). Decreased $\mathrm{K}^{+}$and $\mathrm{Ca}^{2+}$ uptake apparently depresses growth at higher $\mathrm{Na}^{+}$concentrations (Cuartero and Fernandez-Munoz, 1999; Sairam et al., 2002). The $\mathrm{K}^{+}$ deficiency of plants was inversely correlated to the increased accumulation of $\mathrm{Na}^{+}$indicating the existence of competition between $\mathrm{Na}^{+}$and $\mathrm{K}^{+}$ions which most likely share the same transport system at the root surface (Rus et al., 2001). The $\mathrm{Ca}^{2+}$ deficiency in salt stress had been associated to a decreased transpiration rate rather than competition effects with $\mathrm{Na}^{+}$, additionally $\mathrm{Ca}^{2+}$ may 
ameliorate plant response to salinity (Maggio et al., 2006). $\mathrm{Na}^{+}$becomes highly toxic at different physiological levels when absorbed and accumulated at large amount in plant. Physiological impairments caused by $\mathrm{Na}^{+}$toxicity include disruption of $\mathrm{K}^{+}$and $\mathrm{Ca}^{2+}$ nutrition, development of water stress and induction of oxidative cell damage (Aktas et al., 2006). Reduction of $\mathrm{K}^{+}$and $\mathrm{Ca}^{2+}$ ions in plant tissues at high level of $\mathrm{NaCl}$ salt treatments is a very known fact for eggplant, tomato and melon (Savvas and Lenz, 2000), spinach (Wilson et al., 2000), pepper (Aktas et al., 2006), squash plant (Yildirim et al., 2006). Increase in concentrations of $\mathrm{Ca}^{2+}$ and $\mathrm{K}^{+}$in plant under salt stress could improve the harmful effects of salinity on growth and yield (Grattan and Grieve, 1999; Sivritepe et al., 2003; Kaya et al.; 2003). Table 03 indicated that number of fruits/plant were decreased while brinjal plant was exposed to the salinity level $12 \mathrm{dS} / \mathrm{m}$ and $16 \mathrm{dS} / \mathrm{m}$ while Table 04 indicated that fruit length and diameter were reduced in each variety with the increases of the salinity level. Reduction of fruit length and diameter caused the smaller fruit size. It was also found that fresh fruit weight of individual fruit were decreased in both $12 \mathrm{dS} / \mathrm{m}$ and $16 \mathrm{dS} / \mathrm{m}$ salinity compared to the control (Table 05). At higher EC levels the fruit fresh weight was more severely depressed (Savvas and Lenz, 1994b). The more detrimental effects of salinity on the yield than on the vegetative organs of eggplant should be attributed to a restriction of water accumulation in the fruit. Water flow into the fruit under saline conditions is restricted by a lower water potential in the plant (Johnson et al., 1992). Response of water flow into the fruit is osmotic origin and therefore, independent of the salts raising the EC of the nutrient solution in the root environment. A lower water accumulation in the fruit was observed also in tomatoes when they were exposed to increased EC, irrespective of the salinity source (Ehret and Ho, 1986; Adams, 1991; Willumsen et al., 1996). As the plants provided lower number, smaller fruits and lower individual fruit weight at the salinity stress thus ultimately reduced the yield/plant. But this reduction was varied among the germplasms due to their genetic factors. Salt tolerant cultivars are capable of maintaining higher $\mathrm{K}^{+} / \mathrm{Na}^{+}$ratios in tissues (Mansour, 2003; Zeng et al., 2003). Plant growth under $12 \mathrm{dS} / \mathrm{m}$ saline conditions accumulated more of $\mathrm{Na}^{+}$, decreased $\mathrm{Ca}^{2+}$ uptake, reducing $\mathrm{Ca}^{2+} / \mathrm{Na}^{+}$ ratios in root, shoot and leaf. Conversely, some cultivars were more reluctant to lesser $\mathrm{Ca}^{2+} \mathrm{Na}^{+}$ratios thus were less affected by high salt concentrations (Turhan et al., 2009) in tomato. From the current experiment, it was found that some of the brinjal lines were comparatively less affected by both 12 $\mathrm{dS} / \mathrm{m}$ and $16 \mathrm{dS} / \mathrm{m}$ salinity which confirmed the most salt tolerant cultivar. In spite of the negative effect of salt on plant growth and yield in brinjal some varieties appeared to be less affected by salinity treatment. This argument is also similar to the results obtained by Cruz and Cuartero (1990). Salinity stress results in a clear stunting of plant growth, which results in a considerable decrease in growth and yield of brinjal but some of the cultivars were comparatively less affected in salinity stress.

\section{Conclusion}

Plant growth and yield contributing characteristics of Brinjal lines were influenced according to genetical factors of the responsible with lines and salinity levels. Line- $6\left(\mathrm{~V}_{6}\right)$ was best variety for the both the level of $12 \mathrm{dS} / \mathrm{m}$ and $16 \mathrm{dS} / \mathrm{m}$ saline affected area that was closely followed to the Line- $1\left(\mathrm{~V}_{1}\right)$ concerning yield and yield contributing characters.

\section{References}

[1]. Adams, P. (1991). Effects of increasing the salinity of the nutrient solution with major nutrients or sodium chloride on the yield, quality and composition of tomatoes grown in rockwool. Journal HortScience, 66, 201-207. http://dx.doi.org/10.1080/00221589.1991.11516145

[2]. Aktas, H., Abak, K. \& Cakmak, I. (2006). Genotypic variation in the response of pepper to salinity. Scientia Horticulture, 110, 260-266. http://dx.doi.org/10.1016/j.scienta.2006.07.017

[3]. Al-Karaki, G. N. (2000). Growth, water use efficiency and sodium and potassium acquisition by tomato cultivars grown under salt stress. Journal of Plant Nutrition, 23, 1-8. http://dx.doi.org/10.1080/01904160009381992

[4]. Allen, R. G., Pereria, L. S., Raes, D. \& Smith, M. 1998. Crop evapotranspiration. Guidelines for computing crop water requirements. FAO Irrigation and Drainage Paper No. 56.

[5]. Bresler, E., McNeal, B. L. \& Carter, D. L. (1982). Saline and Sodic Soils. Springer-Verlag: Berlin. http://dx.doi.org/10.1007/978-3-642-68324-4 
[6]. Brugnoli, E. \&Lauteri, M. (1991). Effects of salinity on stomatal conductance, photosynthetic capacity, and carbon isotope discrimination of salt-tolerant (Gossypium hirsutum L.) and saltsensitive (Phaseolus vulgaris L.) $\mathrm{C}_{3}$ non-halophytes. Plant Physiology, 95, 628-635.

http://dx.doi.org/10.1104/pp.95.2.628

[7]. Cruz, V. \& Cuartero, J. (1990). Effect of salinity at several developmental stages of six genotypes of tomato (Lycopersicon spp.) In: Cuartero J, Gomez-Guillamon M, Fernandez-Munoz R. Edition, Malaga, Spain, pp. 81-86.

[8]. Cuartero, J. \& Fernandez-Munoz, R. (1999). Tomato and salinity. Scientia Hortic. 78: 83-125. http://dx.doi.org/10.1016/S0304-4238(98)00191-5

[9]. Ehret, D. L. \& Ho, L. C. 1986. The effects of salinity on dry matter partitioning and fruit growth in tomatoes grown in nutrient fillm culture. Journal of Horticultural Sciences, 61, 361-367. http://dx.doi.org/10.1080/14620316.1986.11515714

[10]. Gomez, K. A. \& Gomez, A. A. 1984. Statistical Procedures for Agricultural Research. $2^{\text {nd }}$ edn. John Wiley and Sons. New York. p. 680.

[11]. Grattan, S. R. \& Grieve, C. M. (1999). Salinity-mineral nutrient relations in horticultural crops. Scientia Horticulture, 78, 127-157. http://dx.doi.org/10.1016/S0304-4238(98)00192-7

[12]. Johnson, R. W., Dixon, M. A. \& Lee, D. R. (1992). Water relations of the tomato fruit during growth. Plant Cell Environment, 15: 947-953. http://dx.doi.org/10.1111/j.1365-3040.1992.tb01027.x

[13]. Kaya, C., Higgs, D., Ince, F., Amador, B. M., Cakir, A. \& Sakar, E. (2003). Ameliorative effects of potassium phosphate on salt-stressed pepper and cucumber. Journal of Plant Nutrition, 26, 807-820. http://dx.doi.org/10.1081/PLN-120018566

[14]. Lamsal, K., Paudyal, G. N. \& Saeed, M. (1999). Model for assessing impact of salinity on soil water availability and crop yield. Agricultural Water Management, 41, 57-70.

http://dx.doi.org/10.1016/S0378-3774(98)00116-4

[15]. Maas, E. V. (1984). Salt tolerance of plants. In The Handbook of Plant Science in Agriculture, Christie BR (ed.). CEC Press: Boca Raton, Fla.

[16]. Maggio, A., Raimondi, G., Martino, A. \& Pascale, S. (2006). Salt response in tomato beyond the salinity tolerance threshold. Environmental and experimental botany. Department of Agricultural Engineering and Agronomy of the University of Naples Federico II, Italy 11: 131141.

[17]. Mansour, M. M. F. (2003). Transport proteins and salt tolerance in plants. Plant Sci. 164, 891900. http://dx.doi.org/10.1016/S0168-9452(03)00109-2

[18]. Mondal, M. R. I., Islam, M. S., Jalil, M. A. B., Rahman, M. M., Alam, M. S. \& Rahman, M. H. H. (2011). Krishi projukti hatboi (Handbook of Agro-technology), $5^{\text {th }}$ edition. Bangladesh Agricultural Research Institute, Gazipur-1701, Bangladesh, pp. 407-408.

[19]. Montesano, F. \& Van Iersel, M. W. (2007). Calcium can prevent toxic effects of $\mathrm{Na}^{+}$on tomato leaf photosynthesis but does not restore growth. Journal of the American Society for Horticultural Science, 132, 310-318.

[20]. Munns, R. (2002). Comparative physiology of salt and water stress. Plant Cell Environment, 25, 239-250. http://dx.doi.org/10.1046/j.0016-8025.2001.00808.x

[21]. Munns, R. \& Termaat, A. (1986). Whole-plant responses to salinity. Australian Journal of Plant Physiology, 13, 143-160. http://dx.doi.org/10.1071/PP9860143

[22]. Romero-Aranda, R., Soria, T. \& Cuartero, J. (2001). Tomato plant-water uptake and plant-water relationships under saline growth conditions. Plant Science, 160, 265-272. http://dx.doi.org/10.1016/S0168-9452(00)00388-5

[23]. Rus, A. M., Estan, M. T., Gisbert, C., Garcia-Sogo, B., Serrano, R., Caro, M., Moreno, V. \& Bolarin, M. C. (2001). Expressing the yeast HAL1 gene in tomato increases fruit yield and enhances $\mathrm{K}^{+} / \mathrm{Na}^{+}$ selectivity under salt stress. Plant Cell Environment, 24, 875-880.

http://dx.doi.org/10.1046/j.1365-3040.2001.00719.x

[24]. Sairam, R. K., Rao, K. V. \& Srivastava, G. C. (2002). Differential response of wheat genotypes to long term salinity stress in relation to oxidative stress, antioxidant activity and osmolyte concentration. Plant Science, 163, 1037-1046.

http://dx.doi.org/10.1016/S0168-9452(02)00278-9

[25]. Savvas, D. \& Lenz, F. (2000). Effect of NaCl or nutrient-induced salinity on growth, yield and composition of eggplant grown in rockwooll. Scientia Horticulture, 84, 37-47.

http://dx.doi.org/10.1016/S0304-4238(99)00117-X 
[26]. Serrano, R. \& Rodriquez-Navarro, A. (2001). Ion homeostasis during salt stress in plants. Current Opinion in Cell Biology, 13, 399-404.

http://dx.doi.org/10.1016/S0955-0674(00)00227-1

[27]. Sivritepe, N., Sivritepe, H. O. \& Eris, A. (2003). The effects of $\mathrm{NaCl}$ priming on salt tolerance in melon seedlings grown under saline conditions. Scientia Horticulture 97: 229-237.

http://dx.doi.org/10.1016/S0304-4238(02)00198-X

[28]. Turhan, A., Seniz, V. \& Kuscu, H. (2009). Genotypic variation in the response of tomato to salinity. African Journal of Biotechnology, 8(6), 1062-1068.

[29]. Willumsen, J., Petersen, K. K. \& Kaack, K. (1996). Yield and blossom-end rot of tomato as affected by salinity and cation activity ratios in the root zone. Journal of Horticultural Sciences, 71, 81-98. http://dx.doi.org/10.1080/14620316.1996.11515385

[30]. Wilson, C., Lesch, M. S. \& Grieve, C. M. (2000). Growth stage modulates salinity tolerance of New Zealand spinach and red orach. Annals of Botany, 85, 501-509.

http://dx.doi.org/10.1006/anbo.1999.1086

[31]. Yildirim, E., Taylor, A. G. \& Spittler, T. D. (2006). Ameliorative effects of biological treatments on growth of squash plants under salt stress. Scientia Horticulture, 111, 1-6. http://dx.doi.org/10.1016/j.scienta.2006.08.003

[32]. Zeng, L., Poss, J., Wilson, C., Draz, A. S. E. \& Grieve, C. M. (2003). Evaluation of salt tolerance in rice genotypes by physiological characters. Euphytica, 129, 281-292.

http://dx.doi.org/10.1023/A:1022248522536

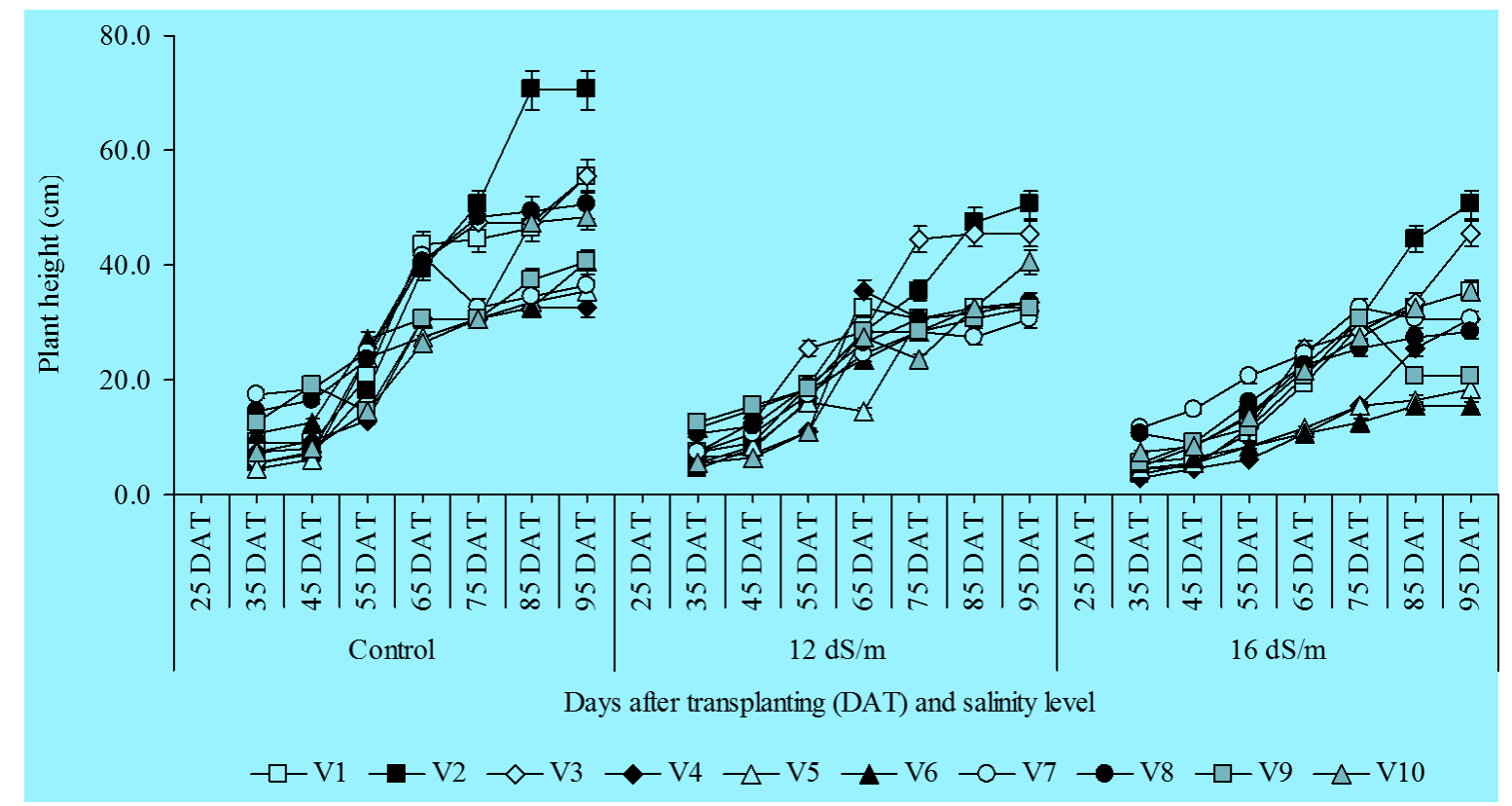

Figure 01. Response of $\mathbf{1 0}$ brinjal lines to plant height on three salinity levels at different days after transplanting. 
Table 01. Leaf area and chlorophyll content of brinjal lines at different salinity level ${ }^{\mathrm{x}}$

\begin{tabular}{|c|c|c|c|c|c|c|c|c|c|c|c|c|}
\hline \multirow{2}{*}{ Line } & \multicolumn{6}{|c|}{ Leaf area $\left(\mathrm{cm}^{2}\right)$ at $40 \mathrm{DAT}$} & \multicolumn{6}{|c|}{ Chlorophyll content (\%) at 40 DAT } \\
\hline & Control & & $12 \mathrm{dS} /$ & & $16 \mathrm{dS} / \mathrm{r}$ & & Control & & $12 \mathrm{dS} / \mathrm{r}$ & & $16 \mathrm{dS} / \mathrm{m}$ & \\
\hline$V_{1}$ & 91.4 & $\mathrm{~d}$ & 54.5 & $\mathrm{C}$ & 40.5 & $\mathrm{~b}$ & 54.5 & $\mathrm{c}$ & 51.6 & $\mathrm{~b}$ & 44.2 & $\mathrm{~b}$ \\
\hline $\mathrm{V}_{2}$ & 37.5 & j & 24.5 & j & 15.8 & $\mathrm{i}$ & 54.3 & $\mathrm{~d}$ & 49.5 & c & 42.2 & c \\
\hline$V_{3}$ & 67.3 & $\mathrm{~h}$ & 47.7 & $\mathrm{f}$ & 22.7 & $\mathrm{~h}$ & 55.0 & $\mathrm{~b}$ & 49.5 & c & 41.6 & e \\
\hline $\mathrm{V}_{4}$ & 44.1 & $\mathrm{i}$ & 28.0 & $\mathrm{i}$ & 7.7 & j & 48.9 & $\mathrm{i}$ & 46.0 & g & 39.4 & $\mathrm{~h}$ \\
\hline $\mathrm{V}_{5}$ & 97.5 & c & 58.6 & $\mathrm{a}$ & 43.6 & a & 53.6 & $\mathrm{e}$ & 49.1 & d & 39.9 & g \\
\hline$V_{6}$ & 106.5 & b & 45.9 & g & 30.6 & $\mathrm{f}$ & 59.2 & $\mathrm{a}$ & 53.5 & $a$ & 44.3 & a \\
\hline $\mathrm{V}_{7}$ & 113.8 & $\mathrm{a}$ & 32.8 & $\mathrm{~h}$ & 25.7 & g & 52.7 & $\mathrm{f}$ & 48.1 & $\mathrm{f}$ & 41.7 & $\mathrm{~d}$ \\
\hline$V_{8}$ & 73.9 & f & 53.4 & $d$ & 36.6 & c & 46.4 & $\mathrm{j}$ & 43.5 & $\mathrm{i}$ & 40.3 & $\mathrm{f}$ \\
\hline$V_{9}$ & 72.0 & g & 56.7 & b & 33.2 & d & 51.1 & h & 45.0 & $\mathrm{~h}$ & 38.5 & $\mathrm{i}$ \\
\hline $\mathrm{V}_{10}$ & 78.2 & $\mathrm{e}$ & 50.7 & $\mathrm{e}$ & 32.4 & $\mathrm{e}$ & 51.7 & $\mathrm{~g}$ & 48.3 & $\mathrm{e}$ & 37.5 & $\mathrm{j}$ \\
\hline LSD0.01 & 0.5 & & 1.0 & & 0.3 & & 0.1 & & 0.1 & & 0.02 & \\
\hline $\mathrm{CV} \%$ & 11.1 & & 9.23 & & 8.56 & & 13.2 & & 11.6 & & 10.8 & \\
\hline
\end{tabular}

Table 02. Days to fruiting and no. of flower bud/plant of brinjal lines at different salinity level ${ }^{x}$

\begin{tabular}{|c|c|c|c|c|c|c|c|c|c|c|c|c|}
\hline \multirow{2}{*}{ Line } & \multicolumn{6}{|c|}{ Days to fruiting } & \multicolumn{6}{|c|}{ No. of flower bud/plant } \\
\hline & Control & & $12 \mathrm{dS} / \mathrm{r}$ & & $16 \mathrm{dS} / \mathrm{r}$ & & Control & & $12 \mathrm{dS} / \mathrm{r}$ & & $16 \mathrm{dS} / \mathrm{m}$ & \\
\hline $\mathrm{V}_{1}$ & 49.4 & $\mathrm{i}$ & 54.4 & i & 62.4 & j & 61.4 & i & 58.4 & $\mathrm{~h}$ & 45.4 & $\mathrm{~g}$ \\
\hline $\mathrm{V}_{2}$ & 75.4 & $\mathrm{c}$ & 79.4 & $\mathrm{~d}$ & 80.4 & e & 64.4 & $\mathrm{~h}$ & 59.4 & $\mathrm{~g}$ & 50.4 & $\mathrm{~d}$ \\
\hline $\mathrm{V}_{3}$ & 94.4 & $\mathrm{a}$ & 98.4 & a & 100.4 & $\mathrm{a}$ & 64.4 & $\mathrm{~h}$ & 58.4 & $\mathrm{~h}$ & 50.4 & $\mathrm{~d}$ \\
\hline $\mathrm{V}_{4}$ & 59.4 & $\mathrm{f}$ & 63.4 & g & 69.4 & $\mathrm{~h}$ & 65.4 & g & 60.4 & $\mathrm{f}$ & 47.4 & $\mathrm{f}$ \\
\hline$V_{5}$ & 82.4 & $\mathrm{~b}$ & 86.4 & $\mathrm{~b}$ & 90.4 & $\mathrm{~b}$ & 68.4 & $\mathrm{e}$ & 62.4 & e & 51.4 & c \\
\hline$V_{6}$ & 52.4 & $\mathrm{~h}$ & 57.4 & $\mathrm{~h}$ & 68.4 & $\mathrm{i}$ & 66.4 & $\mathrm{f}$ & 60.4 & $\mathrm{f}$ & 49.4 & e \\
\hline $\mathrm{V}_{7}$ & 62.4 & $\mathrm{e}$ & 67.4 & $\mathrm{f}$ & 75.4 & $\mathrm{f}$ & 78.4 & $\mathrm{~b}$ & 70.4 & $\mathrm{a}$ & 52.4 & b \\
\hline $\mathrm{V}_{8}$ & 75.4 & $\mathrm{c}$ & 80.4 & $\mathrm{c}$ & 84.4 & $\mathrm{~d}$ & 73.4 & $\mathrm{~d}$ & 64.4 & $\mathrm{~d}$ & 51.4 & $\mathrm{c}$ \\
\hline $\mathrm{V}_{9}$ & 58.4 & g & 63.4 & g & 73.4 & g & 80.4 & $\mathrm{a}$ & 69.4 & b & 53.4 & $\mathrm{a}$ \\
\hline $\mathrm{V}_{10}$ & 66.4 & $\mathrm{~d}$ & 72.4 & $\mathrm{e}$ & 86.4 & c & 75.4 & c & 66.4 & c & 52.4 & $\mathrm{~b}$ \\
\hline$L S D 0.01$ & 1.1 & & 0.9 & & 1.3 & & 0.8 & & 0.6 & & 0.5 & \\
\hline CV\% & 6.8 & & 5.4 & & 3.7 & & 2.7 & & 2.1 & & 1.7 & \\
\hline
\end{tabular}

Table 03. Number of flower/plant and fruit/plant of brinjal lines at different salinity levelx

\begin{tabular}{|c|c|c|c|c|c|c|c|c|c|c|c|c|}
\hline \multirow{3}{*}{$\begin{array}{l}\text { Line } \\
V_{1}\end{array}$} & \multicolumn{6}{|c|}{ No. of flower/plant } & \multicolumn{6}{|c|}{ No. of fruit/plant } \\
\hline & \multicolumn{2}{|c|}{ Control } & \multicolumn{2}{|c|}{$12 \mathrm{dS} / \mathrm{m}$} & \multicolumn{2}{|c|}{$16 \mathrm{dS} / \mathrm{m}$} & \multicolumn{2}{|c|}{ Control } & \multicolumn{2}{|c|}{$12 \mathrm{dS} / \mathrm{m}$} & \multicolumn{2}{|c|}{$16 \mathrm{dS} / \mathrm{m}$} \\
\hline & 56.4 & $\mathrm{i}$ & 54.4 & $\mathrm{f}$ & 39.4 & $\mathrm{f}$ & 47.4 & $\mathrm{a}$ & 34.4 & $\mathrm{a}$ & 20.4 & $\mathrm{~d}$ \\
\hline $\mathrm{V}_{2}$ & 57.4 & $\mathrm{~h}$ & 52.4 & h & 44.4 & $d$ & 40.4 & d & 29.4 & c & 22.4 & b \\
\hline $\mathrm{V}_{3}$ & 59.4 & $\mathrm{f}$ & 53.4 & $\mathrm{~g}$ & 45.4 & $\mathrm{c}$ & 41.4 & $\mathrm{c}$ & 28.4 & $\mathrm{~d}$ & 21.4 & c \\
\hline $\mathrm{V}_{4}$ & 58.4 & $\mathrm{~g}$ & 55.4 & e & 41.4 & $\mathrm{e}$ & 39.4 & e & 30.4 & b & 23.4 & $\mathrm{a}$ \\
\hline$V_{5}$ & 63.4 & $\mathrm{e}$ & 57.4 & $\mathrm{~d}$ & 45.4 & $\mathrm{c}$ & 40.4 & d & 29.4 & $\mathrm{c}$ & 21.4 & $\mathrm{c}$ \\
\hline $\mathrm{V}_{6}$ & 59.4 & $\mathrm{f}$ & 53.4 & g & 44.4 & d & 44.4 & b & 30.4 & b & 22.4 & b \\
\hline$V_{7}$ & 73.4 & b & 65.4 & $\mathrm{a}$ & 47.4 & b & 40.4 & d & 27.4 & $\mathrm{e}$ & 19.4 & $\mathrm{e}$ \\
\hline $\mathrm{V}_{8}$ & 66.4 & $\mathrm{~d}$ & 57.4 & $\mathrm{~d}$ & 44.4 & d & 44.4 & b & 29.4 & $\mathrm{c}$ & 20.4 & d \\
\hline $\mathrm{V}_{9}$ & 74.4 & $\mathrm{a}$ & 62.4 & b & 48.4 & $\mathrm{a}$ & 41.4 & $\mathrm{c}$ & 28.4 & $d$ & 18.4 & $\mathrm{f}$ \\
\hline$V_{10}$ & 69.4 & $\mathrm{c}$ & 60.4 & $\mathrm{c}$ & 45.4 & $\mathrm{c}$ & 40.4 & d & 26.4 & $\mathrm{f}$ & 17.4 & g \\
\hline LSD0.01 & 0.7 & & $0 . .5$ & & 0.5 & & 0.9 & & 0.5 & & 0.5 & \\
\hline CV\% & 4.3 & & 2.8 & & 2.3 & & 3.3 & & 3.1 & & 3.1 & \\
\hline
\end{tabular}


Table 04. Fruit length and diameter of brinjal cultivars at different salinity level ${ }^{x}$

\begin{tabular}{|c|c|c|c|c|c|c|c|c|c|c|c|c|}
\hline \multirow{2}{*}{ Line } & \multicolumn{6}{|c|}{ Fruit length $(\mathrm{cm})$} & \multicolumn{6}{|c|}{ Fruit diameter (mm) } \\
\hline & Control & & $12 \mathrm{dS} / \mathrm{n}$ & & $16 \mathrm{dS} / \mathrm{r}$ & & Control & & $12 \mathrm{dS} / \mathrm{r}$ & & $16 \mathrm{dS} / \mathrm{m}$ & \\
\hline $\mathrm{V}_{1}$ & 12.9 & $\mathrm{a}$ & 11.4 & $\mathrm{a}$ & 9.2 & $\mathrm{a}$ & 50.6 & c & 43.6 & $\mathrm{C}$ & 39.6 & $\mathrm{~b}$ \\
\hline $\mathrm{V}_{2}$ & 9.2 & $\mathrm{~d}$ & 7.9 & $\mathrm{e}$ & 6.6 & e & 36.7 & $\mathrm{~g}$ & 33.7 & $\mathrm{~h}$ & 29.8 & $\mathrm{f}$ \\
\hline $\mathrm{V}_{3}$ & 11.4 & b & 10.3 & b & 8.2 & $\mathrm{c}$ & 42.1 & $\mathrm{~d}$ & 37.2 & $\mathrm{~d}$ & 31.6 & $\mathrm{~d}$ \\
\hline $\mathrm{V}_{4}$ & 9.2 & d & 8.1 & d & 7.0 & $\mathrm{~d}$ & 36.7 & g & 35.2 & g & 29.0 & g \\
\hline$V_{5}$ & 6.3 & $\mathrm{f}$ & 5.2 & g & 4.3 & g & 40.8 & $\mathrm{e}$ & 36.7 & $\mathrm{e}$ & 30.3 & $\mathrm{e}$ \\
\hline $\mathrm{V}_{6}$ & 8.1 & e & 6.9 & $\mathrm{f}$ & 6.2 & $\mathrm{f}$ & 57.7 & a & 54.1 & $\mathrm{a}$ & 42.5 & $\mathrm{a}$ \\
\hline$V_{7}$ & 5.9 & $\mathrm{~g}$ & 5.2 & $\mathrm{~g}$ & 4.3 & $\mathrm{~g}$ & 52.6 & b & 46.8 & b & 37.5 & $\mathrm{c}$ \\
\hline $\mathrm{V}_{8}$ & 5.2 & $\mathrm{i}$ & 4.3 & $\mathrm{i}$ & 3.4 & $\mathrm{i}$ & 36.3 & $\mathrm{~h}$ & 30.6 & $\mathrm{i}$ & 22.3 & $\mathrm{i}$ \\
\hline$V_{9}$ & 10.4 & c & 9.3 & c & 8.4 & $\mathrm{~b}$ & 40.6 & $\mathrm{f}$ & 36.3 & $\mathrm{f}$ & 26.3 & $\mathrm{~h}$ \\
\hline $\mathrm{V}_{10}$ & 5.4 & $\mathrm{~h}$ & 4.7 & $\mathrm{~h}$ & 4.1 & $\mathrm{~h}$ & 29.5 & $\mathrm{i}$ & 26.7 & j & 20.7 & j \\
\hline LSD0.01 & 0.1 & & 0.1 & & 0.1 & & 0.1 & & 0.3 & & 0.4 & \\
\hline $\mathrm{CV} \%$ & 1.2 & & 0.9 & & 0.9 & & 8.6 & & 5.7 & & 3.2 & \\
\hline
\end{tabular}

$\mathrm{x}$ In a column means having similar letter (s) are statistically identical and those having dissimilar letter (s) differ significantly as per 0.01 level of probability

Table 05. Fruit weight and yield/plant of brinjal line at different salinity level ${ }^{x}$

\begin{tabular}{|c|c|c|c|c|c|c|c|c|c|c|c|c|}
\hline \multirow{2}{*}{ Line } & \multicolumn{6}{|c|}{ Fruit weight (g) } & \multicolumn{6}{|c|}{ Yield $(\mathrm{kg}) /$ plant } \\
\hline & Control & & $12 \mathrm{dS} / \mathrm{r}$ & & $16 \mathrm{dS} / \mathrm{r}$ & & Control & & $12 \mathrm{dS} / \mathrm{n}$ & & $16 \mathrm{dS} / \mathrm{m}$ & \\
\hline$V_{1}$ & 76.8 & $\mathrm{~b}$ & 64.6 & $\mathrm{~b}$ & 50.6 & $\mathrm{~b}$ & 3.8 & $\mathrm{~b}$ & 2.4 & $\mathrm{a}$ & 1.2 & $\mathrm{~b}$ \\
\hline $\mathrm{V}_{2}$ & 58.7 & $\mathrm{f}$ & 47.7 & $\mathrm{e}$ & 34.2 & d & 2.5 & $\mathrm{e}$ & 1.5 & $\mathrm{~b}$ & 0.9 & $\mathrm{c}$ \\
\hline $\mathrm{V}_{3}$ & 52.6 & $\mathrm{~h}$ & 40.6 & g & 28.8 & $\mathrm{~g}$ & 2.3 & $\mathrm{f}$ & 1.3 & c & 0.7 & e \\
\hline $\mathrm{V}_{4}$ & 39.6 & j & 30.3 & $\mathrm{j}$ & 18.1 & $\mathrm{j}$ & 1.7 & $\mathrm{~h}$ & 1.1 & d & 0.5 & g \\
\hline$V_{5}$ & 43.5 & i & 31.5 & $\mathrm{i}$ & 18.3 & $\mathrm{i}$ & 1.9 & g & 1.1 & $\mathrm{~d}$ & 0.5 & g \\
\hline$V_{6}$ & 88.7 & $\mathrm{a}$ & 74.8 & $\mathrm{a}$ & 51.7 & $\mathrm{a}$ & 4.1 & a & 2.4 & $\mathrm{a}$ & 1.3 & a \\
\hline$V_{7}$ & 62.8 & d & 51.1 & c & 32.1 & $\mathrm{e}$ & 2.7 & $\mathrm{~d}$ & 1.5 & $\mathrm{~b}$ & 0.8 & d \\
\hline$V_{8}$ & 57.1 & $\mathrm{~g}$ & 40.2 & $\mathrm{~h}$ & 23.6 & $\mathrm{~h}$ & 2.7 & d & 1.3 & $\mathrm{c}$ & 0.6 & $\mathrm{f}$ \\
\hline$V_{9}$ & 64.6 & $\mathrm{c}$ & 49.0 & d & 35.2 & $\mathrm{c}$ & 2.8 & $\mathrm{c}$ & 1.5 & b & 0.8 & $\mathrm{~d}$ \\
\hline $\mathrm{V}_{10}$ & 62.1 & $\mathrm{e}$ & 43.9 & $\mathrm{f}$ & 30.6 & $\mathrm{f}$ & 2.7 & d & 1.3 & $\mathrm{c}$ & 0.7 & $\mathrm{e}$ \\
\hline LSD0.01 & 0.6 & & 0.3 & & 0.1 & & 0.02 & & 0.02 & & 0.02 & \\
\hline CV\% & 7.9 & & 7.1 & & 6.8 & & 0.5 & & 0.3 & & 0.3 & \\
\hline
\end{tabular}

$\mathrm{x}$ In a column means having similar letter (s) are statistically identical and those having dissimilar letter (s) differ significantly as per 0.01 level of probability

Table 06. Performance of best Brinjal lines under salinity in yield related attributes

\begin{tabular}{|c|c|c|c|c|c|}
\hline \multicolumn{6}{|c|}{ At $12 \mathrm{dS} / \mathrm{m}$} \\
\hline Varieties & $\begin{array}{l}\text { No. of } \\
\text { fruit/plant }\end{array}$ & Varieties & $\begin{array}{l}\text { Single fruit } \\
\text { weight (g) }\end{array}$ & Varieties & $\begin{array}{c}\text { Yield } \\
(\mathrm{kg}) / \text { plant }\end{array}$ \\
\hline $\mathrm{V}_{1}$ & 34.4 & $\mathrm{~V}_{6}$ & 74.8 & $\mathrm{~V}_{6}$ and $\mathrm{V}_{1}$ & 2.4 \\
\hline $\mathrm{V}_{4}$ and $\mathrm{V}_{6}$ & 30.4 & $\mathrm{~V}_{1}$ & 64.6 & $\mathrm{~V}_{2}$ & 1.5 \\
\hline \multicolumn{6}{|c|}{ At $16 \mathrm{dS} / \mathrm{m}$} \\
\hline Varieties & $\begin{array}{c}\text { No. of } \\
\text { fruit/plant }\end{array}$ & Varieties & $\begin{array}{l}\text { Single fruit } \\
\text { weight }(\mathrm{g})\end{array}$ & Varieties & $\begin{array}{c}\text { Yield } \\
(\mathrm{kg}) / \text { plant }\end{array}$ \\
\hline $\mathrm{V}_{4}$ & 23.4 & $\mathrm{~V}_{6}$ & 51.7 & $\mathrm{~V}_{6}$ & 1.3 \\
\hline$V_{2}$ and $V_{6}$ & 22.4 & $\mathrm{~V}_{1}$ & 50.6 & $\mathrm{~V}_{1}$ & 1.2 \\
\hline
\end{tabular}

